UDC 378.147:355.23

DOI: https://doi.org/10.31470/2415-3729-2020-11-134-158

Formation of Professional Competence of Future Officers of the Logistics Troops (Forces) Supply of the Armed Forces of Ukraine

\title{
Oleh Maslii
}

Doctor of Philosophy in Pedagogy (Ph.D), Senior researcher, Deputy Academy Commandat for Curriculum and Planning, Head of teaching and instruction department Odesa Military Academy

$\triangle 10$, Fontanska Doroha Str., Odesa, Ukraine, 65000

E-mail: mon2369@ukr.net

ORCID: 0000-0003-2809-2763

\author{
Valentyna Volovnyk \\ Doctor of Philosophy in Pedagogy (Ph.D), Associate Professor, \\ Professor of the Department of Engineering Mechanics \\ Odesa Military Academy \\ $\triangle 10$, Fontanska Doroha Str., Odesa, Ukraine, 65000 \\ E-mail: valvolov9@ukr.net \\ ORCID: 0000-0002-6467-937X
}

\section{Oleksandr Babenko}

Senior researcher,

Scientific department of the organization of training and certification of scientific and pedagogical staff of Scientific and Methodological Center for the Organization of Scientific and Technical Activities.

National Defence University ofUkraine named after Ivan Cherniakhovskyi $\triangle$ 28, Povitroflotskyi Ave., Kiev, Ukraine, 03049

E-mail: opb1953@ukr.net

ORCID: 0000-0003-0694-9279

Дата надходження статті: 15 квітня 2020 p. Стаття прийнята до друку: 01 червня 2020 р. 
Формування фахової компетентності майбутніх офіцерів забезпечення військ (сил) логістики ЗСУ

\section{Олег Миколайович Маслій}

кандидат педагогічних наук, старший науковий співробітник, заступник начальника академії з навчальної роботи

Військова академія

$\triangle$ Фонтанська дорога, 10, м. Одеса, Україна, 65000

\section{Валентина Свгенівна Воловник}

кандидат педагогічних наук, доцент, професор кафедри інженерної механіки

Військова академія

$\triangle$ Фонтанська дорога, 10, м. Одеса, Україна, 65000

\section{Олександр Петрович Бабенко}

старший науковий співробітник наукового відділу організації підготовки та атестації науково-педагогічних кадрів науковометодичного центру організації наукової та науково-технічної діяльності

Національний університет оборони України імені Івана Черняховського

$\triangle$ Повітрофлотський проспект, 28, м. Київ, Україна, 03049

Дата надходження статті: 15 квітня 2020 р. Стаття прийнята до друку: 01 червня 2020 р.

\section{Abstract}

The purpose of the article is to identify the essence and basic principles of formation of professional competence of future logistics officers of the Armed Forces of Ukraine, to determine the algorithm of formation of professional competence by stages of professional training in the higher military educational institution, to identify methods and techniques corresponding to logistics. Research methods: theoretical analysis of primary sources, normative documents, conceptual principles of logistics;

(C) Олег Маслій

(с) Валентина Воловник (C) Олександр Бабенко 
systematization, modeling, observation and testing. The results of the analysis revealed that the professional competence of future logistics officers is a personal education and an integral characteristic, which includes key and general competencies that are the result of training in higher military educational institution, covering the dynamic set of knowledge, skills and experience in this specialty, personal and socially significant qualities (ways of thinking, ability to self-study, learning styles, views, values, nature of behavior in unpredictable conditions, etc.) arising on the basis of the formed subject competences and provide an opportunity to perform the military logistics officer's duties and professional tasks effectively. The principles of forming the professional competence of future logistics officers corresponding to their specialty as they are basic both in military-economic, and in pedagogical logistics are defined. These are: principle of systematization, principle of functionality, principle of integration and integrated goal setting, principle of «just in time», principle of «jit-reliability», principle of solving information problems by standardizing data, principle of prioritizing the needs of learners, principle of variability of strategies, methods and techniques, principle of focusing on the end result, principle of interaction of all components of the professional competence formation system, principle of coordination of actions of different divisions specialists. The influence of these principles on the formation of the future logistics officers' professional competence is analyzed. An algorithm for the formation of professional competence was developed, which was modeled according to two opposite approaches - directions (direct and reverse): «bottom up», it means by stages of professional training in higher military educational institution - a sequence of courses, semesters and levels of training (bachelor, master) of future officers; and «top-down», it means from the principles of professional competence formation through the construction of a «goal tree» and the definition of its components (key competencies) and their manifestations in the material of subjects that form general subject competencies, to building a «competence tree» and designing them for each discipline and definition of subject competencies. There are a number of teaching methods and techniques that take into account the specifics of logistics, such as: methods of empirical adult learning, problem-based learning, the method of planned 
mistakes, visualization methods, methods of press conferences, dialogue, discussions, brainstorming techniques, case studies, which should be used in the educational process to form the professional competence of future logistics officers. Conclusions: the purpose of the study is achieved.

Keywords: professional competence, officers of the logistics troops (forces) supply of the Armed Forces of Ukraine, professional training, higher military educational institution, principles, algorithm, methodology.

\section{References}

1. Vahis, A. (2017). Formuvannia fakhovoi kompetentnosti studenta yak synerhetychnyi protses [Formation of professional competence of a student as a synergetic process]. Ukrainian Journal of Educational Studies and Information Technology, 5, 2, 5-8 [in Ukrainian].

2. Honcharenko, S.U. et al. (Comps.). (2000). Profesiina osvita [Professional education]. Ed. N.H. Nychkalo. Kyiv : Vyshcha shkola [in Ukrainian].

3. Ielnykova, H.V. (2010). Kompetentnisnyi pidkhid do modeliuvannia profesiinoi diialnosti kerivnyka VNZ [Competence approach to modeling the professional activity of the head of the university]. Theory and methods of education management, 4. Retrieved from http://tme.umo.edu.ua/ docs/4/10elneel.pdf [in Ukrainian].

4. Khutorskoi, A.V. (2003). Kliuchovi osvitni kompetentnosti [Key educational competencies]. Retrieved from http://ru.osvita.ua/school/ $\operatorname{method} / 2340 /$ [in Russian].

5. Khutorskoi, A.V. (2013). Kompetentnostnyj podhod v obuchenii [Competence approach in teaching]. Moscow : Publishing House Eidos ; Publishing House of the Institute of Human Education [in Russian].

6. Choshanov, M.A. (1996). Gibkaja tehnologija problemnomodul'nogo obuchenija [Flexible problem-modular learning technology]. Moscow [in Russian].

7. Bohdaniuk, O.D. (2013). Profesiina kompetentnist maibutnikh ofitseriv prykordonnykiv - osnova yakisnoi pidhotovky do sluzhbovoi diialnosti [Professional competence of future border guards is the basis of quality training for service]. Retrieved from https://dspace.uzhnu.edu.ua/ jspui/bitstream/lib/366/1.pdf [in Ukrainian].

(C) Олег Маслій

(C) Валентина Воловник (C) Олександр Бабенко 
8. Halimov, A.V. (2013). Kompetentnist suchasnoho ofitsera yak rezultat profesiinoi osvity : problema vyznachennia [Competence of a modern officer as a result of professional education: the problem of definition]. Journal National Defense University of Ukraine : Questions of pedagogy, 2(33), 32-35 [in Ukrainian].

9. Ievsiukov, O.F. (2006). Pedahohichni umovy formuvannia profesiinoi kompetentnosti maibutnikh ofitseriv u navchalnomu protsesi vyshchoho viiskovoho navchalnoho zakladu [Pedagogical conditions for the formation of professional competence of future officers in the educational process of higher military education]. Extended abstract of candidate's thesis. Kharkiv National Pedagogical University after H.S. Skovoroda [in Ukrainian].

10. Neshchadym, M.I. (2003). Viiskova osvita Ukrainy : istoriia, teoriia, metodolohiia, praktyka : monohrafiia. [Military education of Ukraine : history, theory, methodology, practice : monograph]. Kyiv : Kyiv University Publishing and Printing Center [in Ukrainian].

11. Chernyavskii, O.A. (2012). Fakhova kompetentnist ofitseriv Zbroinykh Syl Ukrainy zi spetsialnoi fizychnoi pidhotovky ta sportu yak osnova profesiinoi maisternosti [Professional competence of officers of the Armed Forces of Ukraine in special physical training and sports as a basis of professional skills]. Journal of Zaporizhia National University, 2(8), 110-116 [in Ukrainian].

12. Iahupov, V.V. (2011). Metodolohichni osnovy rozuminnia ta obgruntuvannia poniat «kompetentnist» i «kompetentsiia» [Methodological bases of understanding and substantiation of the concepts «competence» and «competency»]. New learning technologies: 2 parts. / Ed. Hrebelnyk, O.P. Kyiv, Vinnytsia, 69, 1, 23-29 [in Ukrainian].

13. Iahupov, V.V. (2000). Teoriia i metodyka viiskovoho navchannia [Theory and methods of military training]. Kyiv : Tandem [in Ukrainian].

14. Zakon Ukrainy «Pro vyshchu osvitu» [Law of Ukraine «On Higher Education»]. (n.d.). ru.osvita.ua. Retrieved from http://ru.osvita. ua/legislation/law/2235/ [in Ukrainian].

15. Profesiinyi standart ofitsera taktychnoho rivnia Zbroinykh Syl Ukrainy [Professional standard of a tactical level officer of the Armed 
Forces of Ukraine]. Retrieved from https://nuou.org.ua/assets/documents/ ifk-prof-standart-tr-017-bachelor-1.pdf [in Ukrainian].

16. Volovnyk, V. et al. (2017). Innovations in management education : Logistic approach to the assessment of key competences of students in higher educational institutions. Actual problems of public administration : Studies digest of Odessa regional institute for public administration (ISSN: 1993-8330), 2, 49-53.

17. Jeksperimental'naja teorija obuchenija i stili obuchenija po D. Kolbu. (1984). [Experimental learning theory and learning styles by D. Kolb]. Retrieved from https://4brain.ru/blog/модель-колба/ [in Russian].

\section{Вступ}

Актуальність проблеми підготовки фахово компетентних офіцерів для Збройних Сил України (ЗСУ), зокрема офіцерів забезпечення військ (сил) логістики ЗСУ, підтверджується запитами держави та вимогами до якості підготовки військових фахівців, посиленими в сучасний період військових дій на сході країни.

На нашу думку, серед першочергових завдань реформування військової освіти, спрямованих на підвищення якості професійної підготовки військових фахівців, постає необхідність формування фахової компетентності майбутніх офіцерів у процесі навчання у вищому військовому навчальному закладі (ВВН3), що потребує визначення базових принципів, притаманних даному фаху, і алгоритму формування фахової компетентності згідно $з$ етапами навчальновиховного процесу ВВНЗ. А це безумовно передбачає розробку і впровадження в освітній процес нових методів і методик розвитку фахової компетентності майбутніх офіцерів ЗСУ, відповідних специфіці їхнього фаху.

Компетентність у перекладі з латинської competentia означає коло питань, в яких людина добре обізнана, має знання та досвід. Тобто, людина, яка компетентна в певному фаху (в певній спеціальності, сфері, навіть у кластері як у взаємозамінному елементі локалізованої сфери діяльності визначенного спрямування), повинна мати відповідні знання, вміння, практичні навички та здібності, що дозволять ій

(C) Олег Маслій

(C) Валентина Воловник (C) Олександр Бабенко 
обгрунтовано судити про цю сферу (фах, кластер) й ефективно діяти в ній.

Питання формування і розвитку фахової компетентності спеціалістів у різних сферах діяльності досліджувались багатьма вітчизняними і зарубіжними науковцями (А. Вагіс (Вагіс, 2017), С. Гончаренко (Гончаренко, 2000), Г. Єльникова (Сльникова, 2010), Н. Ничкало (Ничкало, 2010), А. Хуторський (Хуторський, 2003, 2013), М. Чошанов (Чошанов, 1996) та ін.), зокрема у військовій сфері (О. Богданюк (Богданюк, 2013), А. Галімов (Галімов, 2013), О. Свсюков (Євсюков, 2006), М. Нещадим (Нещадим, 2003), О. Чернявський (Чернявський, 2012), В. Ягупов (Ягупов, 2011, 2000) та ін.).

Проте питання формування фахової компетентності майбутніх офіцерів забезпечення військ (сил) логістики ЗСУ у процесі їхньої професійної підготовки у ВВНЗ, визначення базових принципів i алгоритму формування фахової компетентності означених офіцерів згідно з етапами навчально-виховного процесу, виокремлення методів і методик розвитку фахової компетентності майбутніх офіцерів забезпечення військ (сил) ЗСУ, що відповідають специфіці логістики, ще не були предметом окремих досліджень.

Виходячи з поданого, метою статті $є$ виявлення сутності і базових принципів формування фахової компетентності майбутніх офіцерів забезпечення військ (сил) логістики ЗСУ у процесі їхньої професійної підготовки у ВВНЗ, визначення алгоритму формування фахової компетентності означених офіцерів згідно з етапами навчально-виховного процесу ВВНЗ, виокремлення тих методів і методик розвитку фахової компетентності майбутніх офіцерів забезпечення військ (сил), що відповідають специфіці логістики як їхнього майбутнього фаху.

\section{Матеріали і методи досліджень}

Дослідження засноване на розкритті змісту основних принципів формування фахової компетентності майбутніх офіцерів забезпечення військ (сил) логістики ЗСУ, що відповідають специфіці логістики як їхнього майбутнього фаху і є базою для вдосконалення організації їхньої професійної підготовки у ВВНЗ; визначенні алгоритму форму- 
вання фахової компетентності означених офіцерів згідно з етапами навчально-виховного процесу ВВНЗ та використанні відповідних методів і методик навчання на основі аналізу та узагальнення сучасних наукових джерел, з урахуванням специфіки підготовки офіцерів даного фаху.

Аналізуючи підходи науковців А. Вагіс, А. Галімов, Г. Єльникова, А. Хуторськой, О. Євсюков, В. Ягупов) до розуміння сутності фахової компетентності майбутніх спеціалістів, установлено активний вплив особливостей досліджуваного фаху (логістики) на процес іiі формування. При цьому використовувались такі методи дослідження: теоретичний аналіз документів міжнародного та державного рівня щодо стратегії розвитку і реформування військово-професійної освіти, нормативних документів, професійних стандартів офіцерів тактичного рівня ЗСУ (за різним фахом), навчальних планів, освітньопрофесійних програм, концептуальних положень логістики; методи систематизації і побудови педагогічних процесів як систем; методи педагогічного моделювання і розробки моделей алгоритмів процесів; методи емпіричного спостереження і тестування.

\section{Результати та їх обговорення}

Огляд використаної для дослідження літератури засвідчив, що й дотепер не існує єдиного узгодженого визначення фахової компетентності та переліку ключових або загальних компетентностей спеціалістів певного фаху.

За С. Гончаренком і Н. Ничкало, компетентність - це сукупність знань і вмінь, необхідних для ефективної професійної діяльності: вміння аналізувати, передбачати наслідки професійної діяльності, використовувати інформацію (Гончаренко \& Ничкало, 2010: 149).

А. Вагіс, досліджуючи формування фахової компетентності студента як синергетичний процес, пише, що поняття фахової компетентності охоплює сукупність компетенцій: загальнонаукових, соціальноособистісних, інструментальних та професійних, зміст яких визначає якість підготовки фахівця у вищій школі, і стверджує, що в широкому розумінні фахова компетентність є здатністю особистості успішно виконувати професійні завдання і обов'язки; а під фахо- 
вою компетентністю випускника вищого навчального закладу А. Вагіс розуміє його здатність до розв'язання поставлених завдань у професійній сфері, в основі формування якої лежить самостійна робота студентів (Вагіс, 2017: 5).

Інтегративний зміст поняття фахової компетентності відзначив i М. Чошанов, який розглядав компетентність як суму трьох компонентів: мобільності знань; гнучкості методу, що визначає рівень мінімальної компетентності; та критичності мислення, за якою встановлюється рівень медіальної компетентності (Чошанов, 1996: $6-8)$.

Отже, можна дійти висновку, що фахова компетентність $є$ інтегральною характеристикою фахівця, складовими якої $є$ певні компетенції, притаманні даному фаху.

Г. Сльникова звернула увагу на те, що фахова компетентність $\epsilon$ не тільки сукупністю знань, умінь, здібностей, але й готовністю особистості діяти в складній ситуації та вирішувати фахові завдання 3 високим рівнем невизначеності; а головне - це ставлення до професії як до цінності (Сльникова, 2010).

О. Свсюков визначив педагогічні умови формуванняпрофесійної компетентності майбутніх офіцерів у освітньому процесі ВВН3, якот: усвідомлення курсантами значущості та сутності професійної компетентності; включення майбутніх офіцерів у навчальну діяльність на основі створеної моделі компетентності, яку він розглядав як професійно-особистісну, соціально-значущу якісну характеристику майбутнього офіцера, його інтегративну властивість, що орієнтована на неперервне самовдосконалення і самоосвіту (Свсюков, 2007).

Деякі автори зосереджують увагу на окремих складових фахової компетентності як інтегральної особистісної якості фахівця, які вважають найбільш важливими. Це достатньо часто відбувається саме при дослідженні фахової компетентності військових фахівців внаслідок великої складності і відповідальності цієї професії, представникам якої доводиться виконувати професійні завдання в непередбачуваних бойових умовах. 
Так, О. Чернявський, також розглядаючи фахову компетентність майбутнього офіцера як базову, інтегральну якість, що проявляється у високому рівні професіоналізму, здібності до виконання бойових завдань і обов'язків по несенню військової служби, визначив фахову компетентність офіцерів ЗСУ зі спеціальної фізичної підготовки та спорту як основу їхньої професійної майстерності (Чернявський, 2012: 112).

А. Галімов, досліджуючи компетентність сучасного офіцера, встановив, що формування професійно компетентного спеціаліста $\epsilon$ однією із основних цілей підготовки офіцерських кадрів і має бути прогнозованим результатом професійної освіти офіцера - сукупністю набутих особистістю можливостей до професійної діяльності, тобто компетентностей особистості (Галімов, 2013: 35).

Це також, на нашу думку, підкреслює інтегративний характер фахової компетентності, основними категоріями в досліженні якої виступають поняття компетенцій і компетентностей (як можливостей особистості різного змісту і різного рівня). Більшість авторів розділяють ці поняття, вважаючи компетенцію складовою компетентності.

Підсумовуючи, можна дійти висновку, що фахові компетентності - це передусім результат замовлення суспільства на зміст і якість підготовки його громадян у певній сфері, яке щодо кожного фаху виражається в переліку компетентностей і компетенцій більш низького рівня. Зрозуміло, що такий перелік багато в чому визначається вимогами певного соціуму країни щодо даного фаху (сфери діяльності).

Опрацьовані документи міжнародного та державного рівня щодо стратегії розвитку і реформування військово-професійної освіти свідчать, шо досягти узгодженості цих вимог достатньо важко.

Про це свідчить, наприклад, те, що в ході реалізації міжнародного проекту «Визначення та добір ключових компетентностей», який здійснювався Організацією економічного співробітництва й розвитку та національних інститутів освітньої статистики Швейцарії та США, суворого визначення фахових компетентностей вироблено не було (Хуторський, 2003). 
За першою частиною статті 1 Закону України «Про вищу освіту», компетентність - це динамічна комбінація знань, вмінь і практичних навичок, способів мислення, професійних, світоглядних і громадянських якостей, морально-етичних цінностей, яка визначає здатність особи успішно здійснювати професійну та подальшу навчальну діяльність і $є$ результатом навчання на певному рівні вищої освіти (Закон України «Про вищу освіту», 2014).

Зважаючи на це визначення, можна дійти висновку, що встановити сформованість фахової компетентності майбутнього офіцера забезпечення військ (сил) логістики ЗСУ можна тільки наприкінці його підготовки на відповідному рівні вищої освіти (бакалавр, магістр).

У Професійному стандарті офіцера тактичного рівня Збройних Сил України визначено, що «професійні компетентностікомпетентності, що залежать від предметної області, та є важливими для успішної професійної діяльності за певною спеціальністю. Професійні компетенції набуваються під час засвоення загальнопрофесійних навчальних дисциплін, необхідних для базової підготовки зі спеціальності» (Закон України «Про вищу освіту», 2014: 5-6).

Як бачимо, тут відбувся перехід від компетентності до компетенції без будь-яких пояснень, тобто як до однакових понять. Проте більшість науковців у сфері освіти ці поняття розмежовують.

Дослідники рекомендують відрізняти синонімічні поняття «компетенція» та «компетентність» для розподілу загального й індивідуального у змісті фахової компетентнісної освіти (Хуторський, 2013; Ягупов, 2011).

На основі аналізу першоджерел (Хуторський, 2003; Хуторський, 2013; Ягупов, 2011) і з урахуванням цілей даного дослідження приймаємо, що компетенція - це відчужена від суб'єкта, наперед задана вимога (норма) до освітньо-професійної підготовки того, хто навчається (курсанта, слухача), необхідна для його якісної продуктивної діяльності в певній області, окресленій відповідною навчальною дисципліною; а компетентність - це оволодіння, володіння тим, хто навчається, відповідними компетенціями. Компетентність 
включає особистісне ставлення суб'єкта, який навчається, до предмета діяльності, передбачає наявність достатнього досвіду діяльності в цій сфері, досвіду застосування компетенцій, і $є$ його особистісною якістю (сукупністю якостей), що вже відбулась, тобто є результатом певної навчально-практичної підготовки.

Дослідники у сфері освіти (А. Хуторський, В. Ягупов та ін.) пропонують трирівневу ієрархію компетентностей, які, на нашу думку, можуть виступати складовими фахової компетентності майбутнього військового спеціаліста будь-якого фаху, зокрема майбутнього офіцера забезпечення військ (сил) логістики ЗСУ, а саме:

- ключові компетентності - відносяться до загального (метапредметного) змісту освітньо-професійної і вйськово-спеціальної підготовки майбутніх офіцерів забезпечення військ (сил) логістики ЗСУ;

- загальнопредметні компетентності - відносяться до певного кола навчальних дисциплін у різних блоках навчальних модулів програми освітньо-професійної і вйськово-спеціальної підготовки майбутніх офіцерів забезпечення військ (сил) логістики ЗСУ;

- предметні компетентності (компетенції) - частки стосовно двох попередніх рівнів компетентності, що мають конкретний опис i можливість формування в межах дисциплін навчального плану підготовки майбутніх офіцерів забезпечення військ (сил) логістики 3СУ.

На основі проведеного аналізу сутності поняття фахової компетентності визначаємо, що фахова компетентність майбутніх офіцерів забезпечення військ (сил) логістики ЗСУ - це особистісне утворення та інтегральна характеристика, складовими якої виступають ключові і загальні компетентності, що є результатом підготовки у ВВН3, охоплюють одержану у процесі навчання динамічну сукупність знань, умінь, навичок та отриманого досвіду щодо даного фаху, особистих і соціально значущих якостей (способів мислення, здатності до самонавчання, стилей навчання, поглядів, цінностей, характеру поведінки в непередбачуваних умовах тощо), виникають на основі поетапно сформованих предметних компетенцій i забезпечують

(C) Олег Маслій

(C) Валентина Воловник (C) Олександр Бабенко 
можливість ефективно виконувати службові обов’язки і професійні завдання офіцера військової логістики.

Отже, у процесі підготовки військових фахівців при викладанні навчальних дисциплін формування фахової компетентності майбутніх офіцерів полягає насамперед у формуванні конкретних компетенцій у навчальних предметах і відповідних видах діяльності.

Виходячи 3 цього і на основі досліджень науковців (Хуторський, 2003; Хуторський, 2013; Нещадим, 2003; Ягупов, 2000) можна дійти висновку, що алгоритм формування фахової компетентності майбутніх офіцерів забезпечення військ (сил) логістики ЗСУ повинен передбачати виявлення ii базових принципів і певні процедури визначення іiі складових (компетентностей різного рівня та відповідних компетенцій) та складатися із наступних послідовних дій та етапів:

1) виявлення базових принципів формування фахової компетентності майбутніх офіцерів забезпечення військ (сил) логістики ЗСУ у процесі їхньої професійної підготовки у ВВНЗ;

2) визначення складових фахової компетентності майбутніх офіцерів логістики (ключових компетентностей даної військовоосвітньої сфери) і побудова так званого «дерева цілей» стосовно вимог до них, що враховує визначену вище сутність фахової компетентності;

3) визначення проявів установлених складових фахової компетентності майбутніх офіцерів логістики (ключових компетентностей) у матеріалі кожної навчальної дисципліни;

4) на основі виявлених проявів виокремлення загальнопредметних компетентностей, що формуються в певних блоках навчальних дисциплін;

5) встановлення рівня сформованості визначених загальнопредметних компетентностей і побудова так званого «дерева компетентностей»;

6) проєктування загальнопредметних компетентностей на вертикаль навчання за рівнями військової освіти - бакалавр, магістр;

7) проєктування сформованих за рівнями військової освіти компетентностей на горизонталі навчальних предметів, тобто визначен- 
ня предметних компетенцій, та їх відображення у військово-освітніх документах (професійних стандартах офіцерів тактичного рівня логістики ЗСУ за різним фахом, відповідних навчальних програмах, підручниках, методах і методиках підготовки майбутніх офіцерів забезпечення військ (сил) логістики ЗСУ).

Перший етап цього алгоритму щодо виявлення принципів формування фахової компетентності майбутніх офіцерів забезпечення військ (сил) логістики ЗСУ у процесі їхньої професійної підготовки у ВВНЗ повинен, на нашу думку, враховувати принципи логістики, що $є$ базовими як у майбутній професійній діяльності офіцерів логістики ЗСУ (військово-економічна логістика), так і у процесі їхньої професійної підготовки у ВВНЗ (педагогічна логістика), i виявити, яким саме чином ці принципи впливають на формування фахової компетентності майбутніх офіцерів логістики.

До таких принципів логістики можна віднести наступні принципи: системності, функціональності, інтеграції та інтегрального визначення цілей, «точно в термін», «джит-надійності», вирішення інформаційних проблем шляхом стандартизації даних, пріоритету потреб тих, хто навчається, варіативності стратегій, методів і методик, орієнтації на кінцевий результат, взаємодії всіх компонентів логістичної системи і координації дій спеціалістів різних підрозділів (Volovnyk, Dedlovskaya \& Nechayeva, 2017: 49-50)

Згідно принципу системності процес формування фахової компетентності майбутніх офіцерів забезпечення військ (сил) логістики ЗСУ можна розглядати як педагогічну систему, що $є$ цілісною (емерджентною), складною, ієрархічною і адаптивною, тобто логістичною, педагогічною системою.

За принципом функціональності специфіка цієї системи визначається домінуючими функціями (навчання, виховання, формування і розвиток ключових, загальнопредметних компетентностей і предметних компетенцій майбутнього офіцера логістики), а зворотний зв'язок забезпечується функціями контролю і оцінки якості його підготовки та рівня сформованості цих компетентностей і компетенцій.

(C) Олег Маслій

(C) Валентина Воловник (C) Олександр Бабенко 
Принципи інтеграції та інтегрального визначення цілей щодо формування фахової компетентності майбутніх офіцерів логістики ЗСУ обумовлюють дидактичну інтеграцію навчальних дисциплін, розробку інтегрованих модульних курсів підготовки майбутніх офіцерів логістики i, на цій основі, визначення їхніх ключових, загальнопредметних компетентностей і предметних компетенцій, на формування яких спрямовується їхня професійна підготовка у ВВНЗ.

Відповідно принципу «точно в термін» (JIT - just in time) оптимізуються логістичні ланцюжки навчально-виховного процесу формування фахової компетентності майбутніх офіцерів логістики ЗСУ під час їхньої професійної підготовки у ВВНЗ, що відбувається у визначеній просторово-часовій послідовності етапів формування.

Принцип «джит-надійності» (JIT-reliability) базується на здатності логістичної системи до самоорганізації і являє собою спосіб підвищення надійності іï функціонування шляхом резервування інформації, тобто наявності надлишкової інформації (резервів), що слід передбачити при проєктуванні нового інформаційно-освітнього простору, в якому процес формування фахової компетентності майбутніх офіцерів логістики має бути зорієнтований на їхнє неперервне самовдосконалення і самоосвіту.

За принципом рішення інформаційних проблем шляхом стандартизації даних упроваджуються професійні стандарти офіцерів тактичного рівня ЗСУ різного фаху (тобто галузі знань, спеціальності і спеціалізаціі), зокрема офіцерів забезпечення військ (сил) логістики 3СУ, які містять перелік ключових військово-професійних i професійно-спеціальних компетентностей майбутнього офіцера, а також в освітній процес ВВНЗ впроваджуються стандарти підготовки офіцерського складу у військових навчальних закладах країн-членів HATO.

Принцип пріоритету потреб тих, хто навчається (курсантів, слухачів), і потреб ринку праці, означає пріоритет їхніх потреб в аспекті майбутнього працевлаштування, можливості бути захишеними і мобільними на ринку праці на основі досягнутого у процесі навчання у ВВНЗ достатнього рівня сформованості фахової компетентності 
майбутніх офіцерів, зокрема у сфері логістики, що обумовлює обов'язковість органічного взаємозв'язку вищої військової і вищої цивільної освіти, відповідно стандартам підготовки офіцерського складу у військовому училищі Вест-Пойнт (США).

Принципи орієнтації на кінцевий результат, взаємодії всіх компонентів логістичної системи і координації дій спеціалістів різних підрозділів, які приймають участь в управлінні процесами формування фахової компетентності майбутніх офіцерів логістики, обумовлюють впровадження в інформаційно-освітній простір таких методів і методик, що спрямовані на прогнозований кінцевий результат, котрий фіксується в досягненні майбутніми офіцерами забезпечення військ (сил) логістики ЗСУ заданого рівня сформованості фахової компетентності.

Принцип варіативності стратегій, методів і методик щодо управління процесом формування фахової компетентності майбутніх офіцерів логістики виступає основою розробки і впровадження в означений процес методів і методик навчання, що відповідають специфіці логістики як їхнього майбутнього фаху і спрямовані на підвищення рівня сформованості ключових, загальнопредметних компетентностей і предметних компетенцій майбутнього офіцера забезпечення військ (сил) логістики ЗСУ.

Сукупний аналіз наступних етапів розробленого алгоритму формування фахової компетентності при підготовці майбутніх офіцерів забезпечення військ (сил) логістики ЗСУ і визначених базових принципів даного процесу, свідчить, що його реалізація, як педагогічної системи, дійсно повинна передбачити першочергове створення нового інформаційно-освітнього простору, в якому означений процес формування повинен проходити скрізь усі навчальні дисципліни, одержуючи на кожному етапі військово-професійне, практичне, особистісно й соціально важливе відбиття на відповідному матеріалі кожної навчальної дисципліни, зорієнтоване на неперервне самовдосконалення і самоосвіту майбутніх офіцерів. Зрозуміло, що це досить тривалий процес, у результаті якого має відбутися поєднання навчальних дисциплін в єдину, емерджентну і адаптивну, логістичну

(C) Олег Маслій

(C) Валентина Воловник (C) Олександр Бабенко 
педагогічну систему формування фахової компетентності майбутніх офіцерів логістики, вертикальна (просторово-часова, кількісна) вісь якої характеризує рівні навчання, а горизонтальна (якісна) розгалужені міждисциплінарні зв'язки.

Розроблений алгоритм змодельований як би «згори вниз»: від принципів формування фахової компетентності, що враховують специфіку фаху логістики; через побудову «дерева цілей» і визначення складових фахової компетентності (ключових компетентностей) та їх проявів у матеріалі навчальних предметів, які формують загальнопредметні компетентності, що дозволяє, враховуючи їх рівні, побудувати «дерево компетентностей»; і до проєктування цих компетентностей на кожну навчальну дисципліну для визначення предметних компетенцій.

Що стосується алгоритму формування фахової компетентності майбутніх офіцерів забезпечення військ (сил) логістики ЗСУ за етапами навчально-виховного процесу ВВНЗ, тобто за вертикальною віссю даної педагогічної системи, то він проєктується у зворотному порядку, як би «знизу вгору», за послідовністю курсів, семестрів і рівнів начання: бакалавр - 3,5 років (I - VII семестри); магістр - 1,5 року (VIII - X семестри).

I семестр - визначаються предметні компетенції даного періоду, формується загальноосвітня складова фахової компетентності майбутніх офіцерів логістики.

II семестр - починають формуватися професійна і практична складові фахової компетентності: навчальна практика (2 тижні), вихід на полігон (польові заняття - 1 тиждень); професійна складова полягає у підготовці до виконання обов'язків командира механізованого взводу; загальновійськова підготовка відповідає тематиці механізованого відділення; визначаються предметні компетенції дисциплін цього семестру, що виступають складовими загальнопредметних компетентностей; продовжує формуватися загальноосвітня складова фахової компетентності.

III-IV семестри - продовжують формуватися професійна i практична складові фахової компетентності: продовжуються на- 
вчальна практика (2 тижні) і вихід на полігон (польові заняття - 1 тиждень); професійна складова полягає у виконанні обов'язків командира механізованого взводу; загальновійськова підготовка відповідає тематиці механізованого взводу, роти; визначаються предметні компетенції дисциплін цього періоду, що є складовими загальнопредметних компетентностей; завершується формування загальноосвітньої складової фахової компетентності.

$\mathrm{V}$ семестр - продовжують формуватися професійна і практична складові фахової компетентності: вихід на полігон (польові заняття - 1 тиждень); професійна складова полягає у підготовці до виконання обов'язків командира взводу матеріального забезпечення; загальновійськова підготовка відповідає тематиці механізованого батальону; визначаються предметні компетенції дисциплін цього семестру, що виступають складовими загальнопредметних компетентностей.

VI семестр - продовжують формуватися професійна і практична складові фахової компетентності: навчальна практика (2 тижні) i вихід на полігон (польові заняття - 1 тиждень); професійна складова полягає у виконанні обов'язків командира взводу матеріального забезпечення; загальновійськова підготовка відповідає тематиці механізованого батальону; визначаються предметні компетенції дисциплін цього семестру, що виступають складовими загальнопредметних компетентностей.

VII семестр - завершується формування професійної і практичної складових фахової компетентності на рівні бакалавра: вихід на полігон (польові заняття - 1 тиждень); професійна складова полягає у виконанні обов'язків командира взводу матеріального забезпечення; загальновійськова підготовка відповідає тематиці механізованого батальону; визначаються рівні сформованості загальнопредметних компетентностей і предметних компетенцій; встановлюється рівень сфомованости фахової компетентності майбутніх офіцерів забезпечення військ (сил) логістики ЗСУ - бакалаврів.

VIII семестр - формуються професійна і практична складові фахової компетентності магістра військової логістики: вихід

\footnotetext{
(с) Олег Маслій

(C) Валентина Воловник (C) Олександр Бабенко
} 
на полігон (польові заняття - 1 тиждень); професійна складова полягає у підготовці до виконання обов'язків офіцера військової логістики, командира батальону логістики; загальновійськова підготовка відповідає тематиці щодо тактики дій бригади; визначаються предметні компетенції дисциплін цього семестру, що виступають складовими загальнопредметних компетентностей.

IX семестр - продовжують формуватися професійна і практична складові фахової компетентності магістра військової логістики: вихід на полігон (польові заняття - 1 тиждень); професійна складова полягає у виконанні обов'язків офіцера військової логістики, командира батальону логістики; загальновійськова підготовка відповідає тематиці щодо тактики дій бригади; визначаються предметні компетенції дисциплін цього семестру, що виступають складовими загальнопредметних компетентностей.

X семестр - завершується формування професійної i практичної складових фахової компетентності магістра військової логістики: вихід на полігон (польові заняття - 1 тиждень); професійна складова полягає у виконанні обов'язків офіцера військової логістики, командира батальону логістики; загальновійськова підготовка відповідає тематиці щодо тактики дій бригади; визначаються рівні сформованості загальнопредметних компетентностей і предметних компетенцій; встановлюється рівень сфомованости фахової компетентності майбутніх офіцерів забезпечення військ (сил) логістики ЗСУ - магістрів військової логістики.

Першими кроками цього процесу є, на нашу думку, впровадження на предметному і міжпредметному рівнях тих сучасних методів і методик навчання, які притаманні фаху логістики і спрямовані саме на формування відповідних предметних компетенцій.

Оскільки курсантами ВВНЗ є і воїни, які пройшли ООС (АТО), i ті, хто тільки закінчив військовий ліцей або школу, то доцільним вважається застосування сучасної методики навчання дорослих,

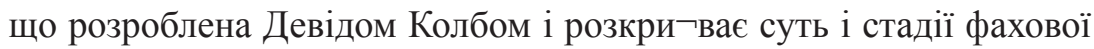
підготовки. 
Провідна ідея моделі емпіричного навчання Девіда Колба полягає у ствердженні, що люди навчаються через діяльність i мислення одним із чотирьох способів: через досвід; через спостереження і рефлексію; за допомогою абстрактної концептуалізації; за допомогою активного експериментування. Виходячи 3 цього, Колб розробив цикл, що повторюється, який потрібен для надбання нових навичок: конкретний досвід (отримання результату дії, тобто «набиття шишок») - рефлексивне спостереження (роздуми над досвідом) - теоретичні концепції (доходження до висновків, планування зміни) - застосування на практиці (експериментальна перевірка). Д. Колб зазначив, що люди не обирають на свідомому рівні, з якого етапу починати. Вони є заручниками своєї моделі поведінки, яка відповідає такій типології людей за підходами до навчання: активіст, мислитель, теоретик, прагматик. Індивідуум чинить якусь дію, потім роздумує над своїм досвідом, приходить до загального висновку і планує зміни в своїй поведінці на майбутнє. Колб стверджував, що істинне навчання неможливе без проходження всіх стадій циклу. Отже, Колб розробив цикл надбання конкретного досвіду, що є однією із головних складових фахової компетентності на певному освітньому рівні (Колб, 1984).

Описана методика навчання дорослих, на наш погляд, може бути використана, насамперед, при проєктуванні загальнопредметних компетентностей і побудові «дерева компетентностей». Її впровадження потребує встановлення на початку навчання шляхом тестування, який стиль пізнання притаманний майбутньому офіцеру логістики. Це допоможе викладачам при використанні методики особистісно орієнтованого навчання.

Проте початковими кроками i основою у формуванні фахової компетентності майбутніх офіцерів забезпечення військ (сил) логістики ЗСУ $є$, на нашу думку, формування предметних компетенцій. Ефективності цього процесу має сприяти використання при підготовці майбутніх офіцерів логістики інтерактивних методів $і$ методик навчання на засадах принципу їх варіативності, як-от: про-

(C) Олег Маслій

(C) Валентина Воловник (C) Олександр Бабенко 
блемне навчання, метод запланованих помилок, метод візуалізації, методи прес-конференції, діалогу, дискусії, методика мозкового штурму, метод аналізу конкретних ситуацій, методика «кейс-стаді» та інші. Це дозволить сформувати одну із основних складових фахової компетентності - здатність до самостійного навчання; отже, й до самостійного формування складових фахової компетентності.

\section{Висновки}

У статті проаналізовано сутність поняття фахової компетентності і виявлено, що фахова компетентність майбутніх офіцерів забезпечення військ (сил) логістики ЗСУ - це особистісне утворення та інтегральна характеристика, складовими якої виступають ключові і загальні компетентності, що є результатом підготовки у ВВНЗ, охоплюють одержану у процесі навчання динамічну сукупність знань, умінь, навичок та отриманого досвіду щодо даного фаху, особистих i соціально значущих якостей (способів мислення, здатності до самонавчання, стилей навчання, поглядів, цінностей, характеру поведінки в непередбачуваних умовах тощо), виникають на основі поетапно сформованих предметних компетенцій і забезпечують можливість ефективно виконувати службові обов'язки і професійні завдання офіцера військової логістики.

Визначено принципи формування фахової компетентності майбутніх офіцерів забезпечення військ (сил) логістики ЗСУ, що відповідають їхньому фаху, оскільки визначені принципи є базовими як у майбутній професійній діяльності офіцерів логістики ЗСУ (військово-економічна логістика), так і у процесі їхньої професійної підготовки уВВНЗ (педагогічна логістика). Це принципи: системності, функціональності, інтеграції та інтегрального визначення цілей, «точно в термін», «джит-надійності», вирішення інформаційних проблем шляхом стандартизації даних, пріоритету потреб тих, хто навчається, варіативності стратегій, методів і методик, орієнтації на кінцевий результат, взаємодії всіх компонентів системи формування фахової компетентності, координації дій спеціалістів різних підрозділів. Проаналізовано, яким чином ці принципи впливають на формування фахової компетентності майбутніх офіцерів логістики. 
Розроблено алгоритм формування фахової компетентності майбутніх офіцерів забезпечення військ (сил) логістики ЗСУ, моделювання якого проводилось за двома протилежними підходами - напрямами побудови алгоритму (прямому і зворотному): «знизу вгору», тобто за етапами навчально-виховного процесу ВВНЗ - послідовністю курсів, семестрів і рівнів начання (бакалавр, магістр) майбутніх офіцерів логістики; і «згори вниз», тобто від принципів формування фахової компетентності через побудову «дерева цілей», визначення складових фахової компетентності (ключових компетентностей), їх проявів у матеріалі навчальних предметів, шо формують загальнопредметні компетентності певних рівнів, до побудови «дерева компетентностей» та проєктування їх на кожну навчальну дисципліну і визначення предметних компетенцій. Напрям «знизу вгору» відповідає вертикальній просторово-часовій (кількісній) вісі системи формування, а напрям «згори вниз» відповідає розгалуженій за горизонталями міждисциплінарних зв'язків предметно-практичній (якісній) вісі педагогічної системи формування фахової компетентності майбутніх офіцерів логістики.

Виокремлено на засадах логістичного принципу варіативності ряд методів і методик навчання, що враховують специфіку фаху логістики, як-от: методика емпіричного навчання дорослих Девіда Колба, проблемне навчання, метод запланованих помилок, метод візуалізації, методи прес-конференції, діалогу, дискусії, методика мозкового штурму, метод аналізу конкретних ситуацій, методика «кейс-стаді» тощо, які слід використовувати у навчальному процесі ВВНЗ для формування і розвитку фахової компетентності майбутніх офіцерів забезпечення військ (сил) логістики ЗСУ.

Перспективи подальших розвідок убачаються в експериментальній перевірці розробленого алгоритму, виокремлених методів і методик для забезпечення високого рівня сформованості фахової компетентності майбутніх офіцерів забезпечення військ (сил) логістики ЗСУ.

(C) Олег Маслій

(C) Валентина Воловник (C) Олександр Бабенко 


\section{Література}

1. Вагіс А. Формування фахової компетентності студента як синергетичний процес. Ukrainian Journal of Educational Studies and Information Technology. Vol. 5. No 2. June 2017. pp. 5-8.

2. Професійна освіта : словник : навч. посіб. / Уклад. С.У. Гончаренко та ін. ; за ред. Н.Г. Ничкало. Київ : Вища школа. 2000. 380 с.

3. Єльникова Г.В. Компетентнісний підхід до моделювання професійної діяльності керівника ВНЗ. Теорія і методика управління освітою. 2010. № 4. URL: http://tme.umo.edu.ua/docs/4/10elneel.pdf (Дата звернення 15.01.2019).

4. Хуторський А.В. Ключові освітні компетентності. URL: http:// ru.osvita.ua/school/method/2340/ (Дата звернення 15.03.2020).

5. Хуторской А.В. Компетентностный подход в обучении : научно-методическое пособие. Москва : Изд-во «Эйдос» ; Изд-во Института образования человека. 2013. 73 с.

6. Чошанов М.А. Гибкая технология проблемно-модульного обучения. Москва, 1996. 160 с.

7. Богданюк О.Д. Професійна компетентність майбутніх офіцерів прикордонників - основа якісної підготовки до службової діяльності. URL: https://dspace.uzhnu.edu.ua/jspui/bitstream/lib/366/1.pdf (Дата звернення 15.03.2020).

8. Галімов А.В. Компетентність сучасного офіцера як результат професійної освіти : проблема визначення. Вісник Національного університету оборони України : Питання педагогіки. 2013. 2 (33). С. 32-35.

9. Свсюков О.Ф. Педагогічні умови формування професійної компетентності майбутніх офіцерів у навчальному процесі вищого військового навчального закладу : дис...канд.пед.наук: 13.00.04. Харківський національний педагогічний університет імені Г.С. Сковороди, 2006. 172 с.

10. Нещадим M.I. Військова освіта Украӥни: історія, теорія, методологія, практика : монографія. Київ : видавничо-поліграфічний центр «Київський університет», 2003. 852 с.

11. Чернявський О.А. Фахова компетентність офіцерів Збройних 
Сил України зі спеціальної фізичної підготовки та спорту як основа професійної майстерності. Вісник Запорізького національного університету. 2012. № 2(8). С. 110-116.

12. ЯгуповВ.В.Методологічніоснови розуміння та обгрунтування понять «компетентність» і «компетенція». Нові технології навчання : [зб. наук. пр. : у 2 ч. / гол. ред. Гребельник О.П.]. Київ. Вінниця, 2011. Вип. № 69, ч. 1. С. 23-29.

13. Ягупов В.В. Теорія $i$ методика військового навчання : монографія. Київ : Тандем, 2000. 380 с.

14. Закон України «Про вищу освіту». URL: http://ru.osvita.ua/ legislation/law/2235/ (Дата звернення 12.03.2020).

15. Професійний стандарт офіцера тактичного рівня Збройних Сил України. URL: https://nuou.org.ua/assets/documents/ifk-profstandart-tr-017-bachelor-1.pdf (Дата звернення 15.05.2020).

16. Volovnyk V., Dedlovskaya M. \& Nechayeva M. Innovations in management education : Logistic approach to the assessment of key competences of students in higher educational institutions. Actual problems of public administration : Studies digest of Odessa regional institute for public administration (ISSN: 1993-8330), Issue 2. 2017. pp. 49-53.

17. Экспериментальная теория обучения и стили обучения по Д. Колбу. URL: https://4brain.ru/blog/модель-колба/ (Дата звернення 15.03.2020).

\section{Формування фахової компетентності майбутніх офіцерів за- безпечення військ (сил) логістики $3 С$ У}

\section{Анотація}

Виявлено сутність і встановлено базові принципи формування фахової компетентності майбутніх офіцерів логістики (системності, функціональності, інтеграції, «точно в термін» і «джит-надійності», стандартизації, варіативності, орієнтації на кінцевий результат, взаємодії і координації дій) та їх вплив на процес формування. Розроблено алгоритм формування за двома протилежними підходами (напрямами): «знизу вгору», тобто за семестрами і рівнями навчан- 
ня (бакалавр, магістр); і «згори вниз», тобто від принципів формування через побудову «дерева цілей», визначення складових фахової компетентності, їх проявів у матеріалі навчальних предметів до «дерева компетентностей» і проєктування їх на дисципліни для визначення предметних компетенцій. Виокремлено ряд методів і методик навчання, що враховують специфіку логістики, зокрема методику емпіричного навчання дорослих.

Ключові слова: фахова компетентність, офіцери забезпечення військ (сил) логістики Збройних Сил України, професійна підготовка, вищий військовий навчальний заклад, принципи, алгоритм, методика.

\section{Формирование профессиональной компетентности будущих офицеров обеспечения войск (сил) логистики ВСУ}

\section{Аннотация}

Выявлена сущность и установлены базовые принципы формирования профессиональной компетентности будущих офицеров логистики (системности, функциональности, интеграции, «точно в срок» и «джит-надежности», стандартизации, вариативности, ориентации на конечный результат, взаимодействия и координации действий) и их влияние на процесс формирования. Разработан алгоритм формирования по двум противоположными подходами (направлениям): «снизу вверх», то есть по семестрам и уровням обучения (бакалавр, магистр); и «сверху вниз», то есть от принципов формирования через построение «дерева целей», определение составляющих профессиональной компетентности, их проявлений в материале учебных предметов до «дерева компетентностей» и проектирования их на дисциплины для определения предметных компетенций. Выделены методы и методики обучения, учитывающие специфику логистики, в том числе методика эмпирического обучения взрослых.

Ключевые слова: профессиональная компетентность, офицеры обеспечения войск (сил) логистики Вооруженных Сил Украины, профессиональная подготовка, высшее военное учебное заведение, принципы, алгоритм, методика. 